\title{
Evaluation of Some Biochemical Parameters of Envenomed Oryctolagus cuniculus
}

Obou Constantin Okou ${ }^{12^{*}}$, Jacques Auguste Alfred Bognan Ackah ${ }^{1}{ }^{2}$, Abba Pacôme Obouayeba ${ }^{1},{ }^{2}$, Djané Hamed $^{1}$, Allico Joseph Djaman ${ }^{2}$

${ }^{1}$ Department of Biochemistry and Microbiology, Agroforestry Training and Research Unit, Jean Lorougnon Guédé University, Côte d'Ivoire

${ }^{2}$ Department of Biology-Health, Biosciences Training and Research Unit, Félix Houphouët-Boigny University Abidjan, Côte d'Ivoire

DOI: $10.36347 /$ saip.2021.v10i01.003

| Received: 26.12.2020 | Accepted: 11.01.2021 | Published: 15.01.2021

*Corresponding author: Obou Constantin Okou

\section{Abstract}

\section{Original Research Article}

The general objective of this study was to evaluate the action of Naja nigricollis venom on certain biochemical parameters of rabbits. To carry out this study, three batches of three rabbits were formed with two control batches and one experimental batch. Each control lot is composed of three rabbits (male or female) while the experimental lot is composed of two males and one female. Each rabbit from the control lots was collected separately from the red tube (dry tube) and transported to the laboratory for analysis. The rabbits from the experimental batch were also collected separately a few minutes after the injection of Naja nigricollis venom for analysis of biochemical parameters. However, prior to these experiments, an in vitro hemolysis test of Naja nigricollis venom was performed on whole blood to verify the hemolysing power of Naja nigricollis venom. The results of this study reveal that:- the venom of Naja nigricollis has a dose-dependent hemolysing power in vitro and in vivo;- with a few exceptions, the biochemical parameters of males are generally higher than those of females;- the venom of Naja nigricollis causes kidney failure and cardiovascular disease in some animals, promotes a risk of coronary death and diabetes in others, causes neuromuscular and cardiac signs due to dyskalemia in others, and finally, a hepatocellular damage or disturbance of bile flow, a heart problem and vitamin B6 deficiency in one type of animal. - the venom of Naja nigricollis is fatal.

Keywords: Venom, Naja nigricollis, biochemical parameters.

Copyright (C) 2021 The Author(s): This is an open-access article distributed under the terms of the Creative Commons Attribution 4.0 International License (CC BY-NC 4.0) which permits unrestricted use, distribution, and reproduction in any medium for non-commercial use provided the original author and source are credited.

\section{INTRODUCTION}

The annual number of ophid bites exceeds 5 millions and the number of people who die from an ophid bite is 125,000 [9, 22]. Worldwide, 500,000 to $5,000,000$ people are estimated to be victims of snakebite poisoning, of whom 50,000 to 150,000 die and 400,000 suffer serious functional sequelae: amputation, kidney failure, neurological sequelae [28, $22,8]$.

Ophidic poisoning in Africa is a public health problem, not only because of its seriousness but also because of the difficulties in treating it [22]. Indeed, in urban Africa, patients with ophidic envenomas can be treated with serotherapy (immunotherapy). It comes from the specific study of venoms based on rigorous biochemical and toxicological analyses [6]. Nevertheless, immunotherapy, which remains the only specific therapy for ophid envenomation, is still very expensive, is available in only a few pharmacies and is constantly in short supply [14]. For rural populations, venomous snake bites are a medical, social and economic problem because of their low income and the distance from medical centers [16]. In the Maghreb, as in sub-Saharan countries, venomous snakes considered more dangerous are represented by Viperidae and Elapidae [25, 21].

Naja melanoleuca, Naja nigricollis, Naja haje... are among the Elapidae found in Africa [26]. The Naja nigricollis has a venom containing toxins that can rapidly immobilize a (neurotoxic) prey [23]. These toxins are polypeptides and proteins, small in size (PM $<30 \mathrm{kDa}$ ) and represent 50 to $70 \%$ of the dry weight of Elapidae venoms [23]. These proteins can act alone or in synergy with other components of the venom to cause serious disturbances in the body's biological systems. These disturbances are responsible for the oedema, hematological, neurological, renal, and

Citation: Obou Constantin Okou et al. Evaluation of Some Biochemical Parameters of Envenomed Oryctolagus Cuniculus.

Sch Acad J Pharm, 2021 Jan 10(1): 13-18. 
Obou Constantin Okou et al., Sch Acad J Pharm, Jan, 2021; 10(1): 13-18

pulmonary and tissue necrosis that are characteristic of ophid envenomation $[27,4,17]$.

This study was conducted in order to understand the action that the venom of Naja nigricollis can have on certain biochemical parameters.

\section{MATERIALS AND METHODS \\ MATERIAL \\ Animal material}

For this study, nine rabbits including five males and four females of Hyplus breed, aged two and a half months were purchased from a breeder in the locality of Daloa (Côte d'Ivoire). After the acclimatization period the weight of the rabbits varied between 1.45 and $2.4 \mathrm{~kg}$. Beside this animal model, the venom of Naja nigricollis (spitting cobra) was also used and supplied by the Pasteur Institute of Adiopodoumé (Côte d'Ivoire).

\section{METHODS}

\section{In vitro hemolysis test method}

Two control lots (lot 1 and lot 2) were established for this test. Lot 1 consists of three males and lot 2 consists of three females. Among these control lots, a blood sample was taken from one of them in order to perform the in vitro hemolysis test of Naja nigricollis venom. To perform this test, 10 tubes were used, including a control tube and 9 experimental tubes. The stock solution was prepared in tube 1 by dissolving $1.6 \mathrm{mg}$ of venom crystals in $1 \mathrm{~mL}$ of physiological water. In the remaining 9 tubes (tubes 2 to 10) a volume of $0.5 \mathrm{~mL}$ of physiological water was added. The venom concentration ranges were prepared using the double dilution technique of geometric ratio $1 / 2$. It consisted in taking $0.5 \mathrm{~mL}$ of the stock solution (tube 1) and transferring it to $0.5 \mathrm{~mL}$ of physiological water from tube 2 and homogenizing it. This procedure was repeated up to tube 9 . From tube 9, a volume of $0.5 \mathrm{~mL}$ was collected and subsequently discarded. Thus, concentrations in the tubes ranged from $1.6 \mathrm{mg} / \mathrm{mL}$ to $6.26 .10^{-3} \mathrm{mg} / \mathrm{mL}$. To these 9 experimental tubes and to the control tube (tube 10), 5 drops of rabbit whole blood was added and homogenized manually. After homogenization, all preparations were incubated at room temperature for 30 to 40 minutes for microscopic observation. This observation was carried out at magnification 40 (X40). For this purpose, the preparations in tubes 1 (SS); 2; 3 and tube 10 (control tube) were diluted distinctly to $1 / 5$ th. Then each dilution was spread between slide and slide by putting the dilution of tube 10 (control) and an experimental dilution (e.g. tube 1). This last operation was also performed for tube 2 and tube 3 .

\section{Method of blood collection}

In general, blood samples were taken from the short saphenous vein and/or the femoral vein. The restraint method was performed by three people. The areas where these veins were located were previously exposed with a pair of scissors. The vacutainers into which the needles were inserted allowed the sampling to be carried out using the red tubes (dry tubes). The resulting tubes were stored in a cooler containing ice and then transported to the laboratory for analysis.

\section{Method of carrying out experimental tests}

For the experimental tests, a quantity of $2 \mathrm{mg}$ of venom crystals were dissolved in $0.5 \mathrm{~mL}$ of physiological solution to have a concentration of 4 $\mathrm{mg} / \mathrm{mL}$. This concentration was injected into the rabbits. Indeed, according to [15], the median lethal dose for a $2 \mathrm{~kg}$ rabbit is $2 \mathrm{mg} / \mathrm{kg}$ body weight by intramuscular injection.

\section{RESULTS AND DISCUSSION \\ RESULTS}

\section{Result of the hemolysing power of venom in vitro}

Figures 1 ( $\mathrm{a}$ and $\mathrm{b}) ; 2$ ( $\mathrm{a}$ and $\mathrm{b}$ ) and 3 ( $\mathrm{a}$ and $\mathrm{b}$ ) are the results of the effects of different concentrations of the venom tested in vitro on red blood cells. These figures show that, in general, the density of red blood cells varies compared to the control depending on the concentrations tested. However, this density is higher when the concentration is low $(0.4 \mathrm{mg} / \mathrm{mL})$ and low when the concentration is high $(1.6 \mathrm{mg} / \mathrm{mL})$.
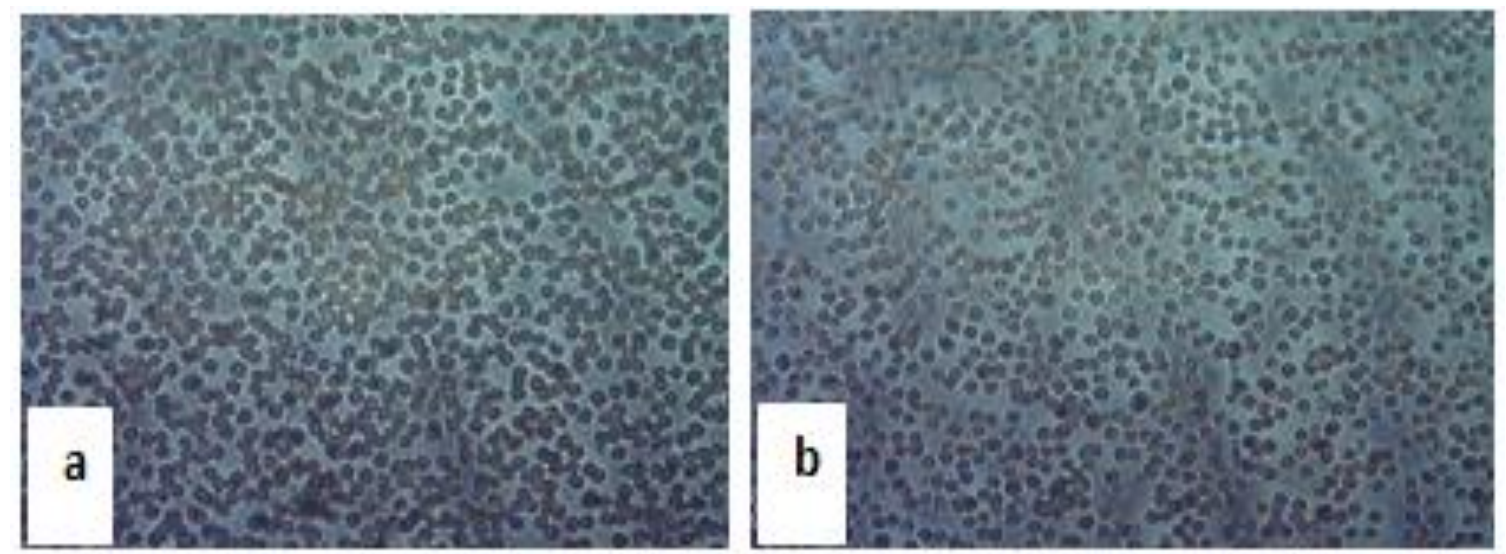

Fig-1: Hemolysing power of venom on red blood cells (at 40 magnifications) 1.a: control red blood cells; $1 . b$ : red blood cells at a concentration of $0.4 \mathrm{mg} / \mathrm{mL}$ venom 
Obou Constantin Okou et al., Sch Acad J Pharm, Jan, 2021; 10(1): 13-18

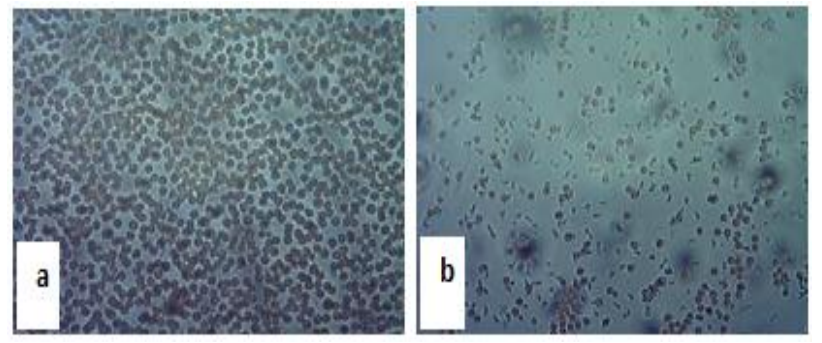

Fig-2: Hemolysing power of venom on red blood cells (at 40 magnifications) 2.a: control red blood cells; 2 .b: red blood cells at a concentration of $0.8 \mathrm{mg} / \mathrm{mL}$ venom

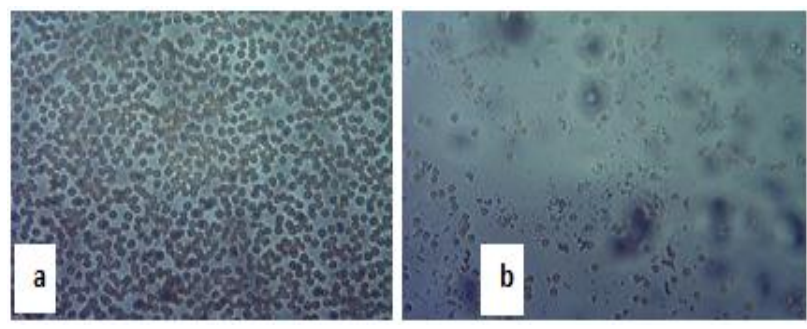

Fig-3: Hemolysing power of venom on red blood cells (at magnification 40) 3.a: control red blood cells; 3.b: red blood cells at a concentration of $1.6 \mathrm{mg} / \mathrm{mL}$ venom

\section{Results of biochemical parameters of control rabbit} batches

The results of the biochemical parameters of the control rabbit batches are reported in Table 1 below.
In this table, the reference value for the biochemical parameters of:

- blood glucose is $193.8 \pm 24.77 \mathrm{mg} / \mathrm{dL}$ for males and $152.32 \pm 17.35 \mathrm{mg} / \mathrm{dL}$ for females;

- creatine values are $18.38 \pm 1.44 \mathrm{mg} / \mathrm{L}$ for males and $15.87 \pm 1.83 \mathrm{mg} / \mathrm{L}$ for females;

- uremia levels are $45.93 \pm 3.55 \mathrm{mg} / \mathrm{L}$ for males and $39.66 \pm 4.57 \mathrm{mg} / \mathrm{L}$ for females;

- GOT/ASAT values are 87.1 $\pm 75.99 \mathrm{IU} / \mathrm{L}$ for males and $124.57 \pm 46.92 \mathrm{IU} / \mathrm{L}$ for females;

- the GPT/ALAT value is $81.12 \pm 44.09 \mathrm{mg} / \mathrm{L}$ for males and $13.76 \pm 15.81 \mathrm{mg} / \mathrm{L}$ for females;

- triglycerides are $344.71 \pm 127.18 \mathrm{mg} / \mathrm{dL}$ for males and $154.16 \pm 37.64 \mathrm{mg} / \mathrm{dL}$ for females;

- total cholesterol is $94.12 \pm 23.08 \mathrm{mg} / \mathrm{dL}$ for males and $112.96 \pm 16.26 \mathrm{mg} / \mathrm{dL}$ for females;

- HDLc value is $26.16 \pm 33.86 \mathrm{mg} / \mathrm{dL}$ for males and $68.07 \pm 12.69 \mathrm{mg} / \mathrm{dL}$ for females;

- LDLc values are $122.67 \pm 184.78 \mathrm{mg} / \mathrm{dL}$ for males and $20.87 \pm 12.88 \mathrm{mg} / \mathrm{dL}$ for females;

- sodium is $132.87 \pm 7.72 \mathrm{mmol} / \mathrm{L}$ for the male and $141.9 \pm 175 \mathrm{mmol} / \mathrm{L}$ for the female;

- chlorine values are $107.43 \pm 10.22 \mathrm{mmol} / \mathrm{L}$ for males and $101.5 \pm 0.62 \mathrm{mmol} / \mathrm{L}$ for females,

- potassium is $3.93 \pm 0.13 \mathrm{mmol} / \mathrm{L}$ for males and $4 \pm$ $0 \mathrm{mmol} / \mathrm{L}$ for females.

Table-1: Biochemical parameters of control batches

\begin{tabular}{|c|c|c|c|c|c|c|c|c|c|c|c|c|c|}
\hline \multirow{2}{*}{$\begin{array}{l}\text { Lo } \\
\text { ts }\end{array}$} & \multirow{2}{*}{\begin{tabular}{|l|} 
Individual \\
$\mathrm{S}$
\end{tabular}} & \multirow{2}{*}{ Gly } & \multirow{2}{*}{ Creat. } & \multirow{2}{*}{ Urea } & \multicolumn{2}{|c|}{ Transaminases } & \multirow{2}{*}{$\mathrm{TG}$} & \multirow{2}{*}{$\mathrm{TC}$} & \multirow{2}{*}{ HDLc } & \multirow{2}{*}{ LDLc } & \multicolumn{3}{|c|}{ Ionogram } \\
\hline & & & & & GOT & GPT & & & & & $\mathrm{Na}$ & $\mathrm{Cl}$ & $\mathrm{K}$ \\
\hline \multicolumn{14}{|c|}{ Biochemical parameters of the male control batch } \\
\hline \multirow{5}{*}{$\begin{array}{l}\text { Lo } \\
\text { t } 1\end{array}$} & MW 1 & 185.2 & 17.38 & 43.45 & 121.41 & 126.52 & 198.02 & 69.33 & 9.09 & 20.63 & 124.5 & 116.4 & 3.78 \\
\hline & MW 2 & 221.72 & 17.74 & 44.35 & 139.88 & 78.37 & 411.98 & 98.04 & 4.23 & 11.42 & 134.4 & 96.3 & 4 \\
\hline & MW 3 & 174.47 & 20.03 & 50 & 0 & 38.47 & 424.12 & $\begin{array}{l}114.9 \\
8\end{array}$ & 65.15 & 335.97 & 139.7 & 109.6 & 4 \\
\hline & Average & 193.8 & 18.38 & 5.93 & 87.1 & 81.12 & 344.71 & 94.12 & 26.16 & 122.67 & 132.87 & 107.43 & 3.93 \\
\hline & $\begin{array}{l}\text { Standard } \\
\text { deviation }\end{array}$ & 24.77 & 1.44 & 3.55 & 75.99 & 44.09 & 127.18 & 23.08 & 33.86 & 184.78 & 7.72 & 10.22 & 0.13 \\
\hline \multicolumn{2}{|c|}{$\begin{array}{l}\text { Reference } \\
\text { value }\end{array}$} & $\begin{array}{l}\text { 169.03- } \\
218.57 \\
\end{array}$ & $\begin{array}{l}16.94- \\
19.82\end{array}$ & $\begin{array}{l}42.38- \\
49.48\end{array}$ & $\begin{array}{l}\text { 11.11- } \\
163.09\end{array}$ & $\begin{array}{l}37.03- \\
125.21 \\
\end{array}$ & \begin{tabular}{|l|}
$217.53-$ \\
471.89 \\
\end{tabular} & $\begin{array}{l}71.04- \\
117.2 \\
\end{array}$ & $\begin{array}{l}-7.7- \\
60.02 \\
\end{array}$ & $\begin{array}{l}-62.11- \\
307.45\end{array}$ & \begin{tabular}{|l|}
$125.15-$ \\
140.59 \\
\end{tabular} & \begin{tabular}{|l|} 
97.21- \\
117.65 \\
\end{tabular} & $\begin{array}{l}3.8- \\
4.06 \\
\end{array}$ \\
\hline \multicolumn{14}{|c|}{ Biochemical parameters of the female control batch } \\
\hline \multirow{5}{*}{$\begin{array}{l}\text { Lo } \\
\text { t } 2\end{array}$} & FW 1 & 134.02 & 14 & 35 & 80.78 & 0.56 & 120.62 & $\begin{array}{l}106.1 \\
9\end{array}$ & 64.83 & 17.24 & 143.6 & 100.8 & 4 \\
\hline & FW 2 & 154.4 & 15.94 & 39.85 & 118.83 & 31.29 & 194.87 & $\begin{array}{l}131.4 \\
7 \\
\end{array}$ & 57.32 & 35.18 & 142 & 101.7 & 4 \\
\hline & FW 3 & 168.53 & 17.66 & 44.14 & 174.09 & 9.44 & 147 & $\begin{array}{l}101.2 \\
1 \\
\end{array}$ & 82.07 & 10.2 & 140.1 & 102 & 4 \\
\hline & Average & 152.32 & 15.87 & 39.66 & 124.57 & 13.76 & 154.16 & $\begin{array}{l}112.9 \\
6\end{array}$ & 68.07 & 20.87 & 141.9 & 101.5 & 4 \\
\hline & $\begin{array}{l}\text { Standard } \\
\text { deviation }\end{array}$ & 17.35 & 1.83 & 4.57 & 46.92 & 15.81 & 37.64 & 16.26 & 12.69 & 12.88 & 1.75 & 0.62 & 0 \\
\hline \multicolumn{2}{|c|}{$\begin{array}{l}\text { Reference } \\
\text { value }\end{array}$} & $\begin{array}{l}134.97- \\
169.67\end{array}$ & $\begin{array}{l}14.04- \\
17.7\end{array}$ & $\begin{array}{l}35.09- \\
44.23\end{array}$ & $\begin{array}{l}77.65- \\
171.49\end{array}$ & $\begin{array}{l}-2.05- \\
29.57\end{array}$ & $\begin{array}{l}116.52- \\
191.8\end{array}$ & $\begin{array}{l}96.7- \\
129.2 \\
2 \\
\end{array}$ & $\begin{array}{l}\text { 55.38- } \\
\text { 80.76 }\end{array}$ & $\begin{array}{l}7.99- \\
33.75\end{array}$ & $\begin{array}{l}140.15- \\
143.65\end{array}$ & $\begin{array}{l}100.88- \\
102.12\end{array}$ & 4 \\
\hline
\end{tabular}

Glyc : glycemia (mg/dL); Creat : creatinine $(\mathrm{mg} / \mathrm{L})$; Urea $(\mathrm{mg} / \mathrm{L})$; Transaminases (GOT and GPT en UI/L) ; TG : triglycerides $(\mathrm{mg} / \mathrm{dL}) ; \mathrm{TC}$ : total cholestérol (mg/dL) ; HDLc : HDL cholesterol (mg/dL) ; LDLc : LDL cholesterol (mg/dL) ; Na : sodium $(\mathrm{mmol} / \mathrm{L}) ; \mathrm{Cl}:$ chlorine $(\mathrm{mmol} / \mathrm{L}) ; \mathrm{K}:$ potassium $(\mathrm{mmol} / \mathrm{L})$. MW : Male witness $; \mathrm{FW}:$ Female witness 
Obou Constantin Okou et al., Sch Acad J Pharm, Jan, 2021; 10(1): 13-18

\section{Result of the biochemical parameters of the batch of} envenomed rabbits

In table 2 are the results of the biochemical parameters of the batch of rabbits that were envenomed. Analysis of these results reveals that:

- all individuals in the experimental batch died;

- in male M1, creatinine, uremia, triglycerides, LDLc and potassium $(\mathrm{K})$ are above their respective reference values, whereas sodium is below its reference value. Apart from these parameters the others are in their respective norm;
- at the M2 male level, blood glucose and triglycerides are beyond their respective standards, while transaminases (GOT and GPT), sodium (Na) and potassium $(\mathrm{K})$ are within their respective reference values. Regardless of these, the other parameters are normal;

- at the F1 level, blood glucose, creatinine, urea, transaminases, LDLc and ionograms $(\mathrm{Na}, \mathrm{Cl}$ and $\mathrm{K})$ have high values compared to their respective standards, unlike HDLc. Triglycerides and total cholesterol are normal.

Table-2: Biochemical parameters of the poisoned batch

\begin{tabular}{|c|c|c|c|c|c|c|c|c|c|c|c|c|c|}
\hline \multirow{2}{*}{\multicolumn{2}{|c|}{ Lots }} & \multirow{3}{*}{\begin{tabular}{|l|} 
Gly \\
193.8 \\
\end{tabular}} & \multirow{3}{*}{\begin{tabular}{|l|}
$\begin{array}{l}\text { Crea } \\
\text { t. }\end{array}$ \\
18.38 \\
\end{tabular}} & \multirow{3}{*}{$\begin{array}{l}\text { Urea } \\
45.93 \\
\end{array}$} & \multicolumn{2}{|c|}{ Transaminases } & \multirow[t]{2}{*}{ TG } & \multirow[t]{2}{*}{ TC } & \multirow[t]{2}{*}{ HDLc } & \multirow[t]{2}{*}{ LDLc } & \multicolumn{3}{|c|}{ Ionogram } \\
\hline & & & & & GOT & GPT & & & & & $\mathrm{Na}$ & $\mathrm{Cl}$ & $\mathrm{K}$ \\
\hline \multirow{2}{*}{$\begin{array}{l}\text { Lot } 1 \\
\text { (MW) }\end{array}$} & Ave & & & & 87.1 & 81.12 & 344.71 & 94.12 & 26.16 & 122.67 & 132.87 & 107.43 & 3.93 \\
\hline & $\mathrm{Sd}$ & 24.77 & 1.44 & 3.55 & 75.99 & 44.09 & 127.18 & 23.08 & 33.86 & 184.78 & 7.72 & 10.22 & 0.13 \\
\hline \multicolumn{2}{|c|}{$\begin{array}{l}\text { Reference } \\
\text { value }\end{array}$} & $\begin{array}{l}169.03 \\
- \\
218.57 \\
\end{array}$ & \begin{tabular}{|l|}
16.94 \\
- \\
19.82 \\
\end{tabular} & $\begin{array}{l}42.38- \\
49.48\end{array}$ & $\begin{array}{l}\text { 11.11- } \\
163.09\end{array}$ & $\begin{array}{l}37.03- \\
125.21\end{array}$ & $\begin{array}{l}217.53 \\
- \\
471.89 \\
\end{array}$ & $\begin{array}{l}\text { 71.04- } \\
117.2\end{array}$ & $\begin{array}{l}-7.7- \\
60.02\end{array}$ & $\begin{array}{l}-62.11- \\
307.45\end{array}$ & $\begin{array}{l}125.15- \\
140.59\end{array}$ & $\begin{array}{l}\text { 97.21- } \\
117.65\end{array}$ & $\begin{array}{l}3.8- \\
4.06\end{array}$ \\
\hline \multirow{2}{*}{$\begin{array}{l}\text { Lot } 2 \\
(\mathrm{FW})\end{array}$} & Ave & 152.32 & 15.87 & 39.66 & 124.57 & 13.76 & 154.16 & 112.96 & 68.07 & 20.87 & 141.9 & 101.5 & 4 \\
\hline & $\mathrm{Sd}$ & 17.35 & 1.83 & 4.57 & 46.92 & 15.81 & 37.64 & 16.26 & 12.69 & 12.88 & 1.75 & 0.62 & 0 \\
\hline \multicolumn{2}{|c|}{$\begin{array}{l}\text { Reference } \\
\text { value }\end{array}$} & $\begin{array}{l}134.97 \\
- \\
169.67 \\
\end{array}$ & \begin{tabular}{|l|}
14.04 \\
-17.7
\end{tabular} & $\begin{array}{l}35.09- \\
44.23\end{array}$ & $\begin{array}{l}77.65- \\
171.49\end{array}$ & $\begin{array}{l}-2.05- \\
29.57\end{array}$ & $\begin{array}{l}116.52 \\
-191.8\end{array}$ & $\begin{array}{l}96.7- \\
129.22\end{array}$ & $\begin{array}{l}55.38- \\
80.76\end{array}$ & $\begin{array}{l}\text { 7.99- } \\
33.75\end{array}$ & $\begin{array}{l}\text { 140.15- } \\
143.65\end{array}$ & $\begin{array}{l}\text { 100.88- } \\
102.12\end{array}$ & 4 \\
\hline \multirow{4}{*}{ Lot 3} & & & & & & & & & & & & & \\
\hline & $\begin{array}{l}\mathrm{M} \\
1 \\
\end{array}$ & 181.22 & 11.82 & 29.63 & 58.02 & 48.83 & 120.55 & 90.81 & 9.08 & 58.01 & 171.1 & 110.02 & 3.1 \\
\hline & $\begin{array}{l}M \\
2 \\
\end{array}$ & 154.15 & 19.39 & 48.51 & 219.22 & 172.52 & 77.73 & 104.27 & 20.09 & 67.73 & 165.4 & 106.42 & 7.54 \\
\hline & $\begin{array}{l}\mathrm{F} \\
1 \\
\end{array}$ & 172.2 & 20.64 & 51.6 & 381.85 & 171.08 & 174.01 & 116 & 29.96 & 49.33 & 229.3 & 130.01 & 9.72 \\
\hline
\end{tabular}

\begin{tabular}{|l|}
\hline Legend \\
\hline Male \\
\hline Lower value \\
\hline Higher value \\
\hline Female \\
\hline Lower value \\
\hline Higher value \\
\hline
\end{tabular}

This Legend applies to the other tables that follow.

\begin{tabular}{|l|}
\hline Status \\
\hline Death \\
\hline Death \\
\hline Death \\
\hline
\end{tabular}

Glyc : glycemia (mg/dL); Creat : creatinine (mg/L) ; Urea $(\mathrm{mg} / \mathrm{L})$; Transaminases (GOT and GPT en UI/L) ; TG : triglycerides $(\mathrm{mg} / \mathrm{dL}) ; \mathrm{TC}$ : total cholestérol $(\mathrm{mg} / \mathrm{dL})$; HDLc : HDL cholesterol (mg/dL) ; LDLc : LDL cholesterol $(\mathrm{mg} / \mathrm{dL}) ; \mathrm{Na}: \operatorname{sodium}(\mathrm{mmol} / \mathrm{L}) ; \mathrm{Cl}:$ chlorine $(\mathrm{mmol} / \mathrm{L})$; $\mathrm{K}$ : potassium (mmol/L). MW: Male witness; FW: Female witness; Ave : Average ; Sd : Standard deviation

\section{DISCUSSION}

\section{Result of the hemolysing power of venom in vitro}

The results of the in vitro hemolysis test showed that, in general, the venom of Naja nigricollis has a hemolysing effect on rabbit whole blood. But these effects are dependent on its concentration. Indeed, hemolysis is more important when the concentration is high. This explains why the density is low with the concentration of $1.6 \mathrm{mg} / \mathrm{mL}$, whereas it is higher with the lowest concentration used $(0.4 \mathrm{mg} / \mathrm{mL})$. This gradual venom action would imply that this effect would be a function of the quantity injected. Thus, venom has a dose-dependent action on red blood cells in vitro. These results are in agreement with those of [7]. This author indicates that the effect of Elapidae venom is proportional to the quantity of toxin molecules introduced into the organism.

\section{Result of the biochemical parameters of the control rabbit batches and the envenomed rabbit batch \\ Comparison of the results of the reference values in Table 1 shows that with the exception of the parameters of GOT, total cholesterol, HDLc and sodium, the parameters of males are generally higher than those of females. According to [13], the variation in the blood content of these different biochemical elements is a function of sex, reproductive cycle, age and growth of rabbits. However, all the biochemical parameters of the control batches obtained during this study are, with a few exceptions, consistent with those of [10].}

At M1 and F1, there is an increase in both creatinine and urea values. According to [1, 19, 31, 28], an increase in serum urea concentration associated with creatinine would indicate renal failure. Therefore, it is possible to infer that males M1 and F1 would obey this 
Obou Constantin Okou et al., Sch Acad J Pharm, Jan, 2021; 10(1): 13-18

assertion. There is also an increase in triglycerides in M1 and M2, LDLc and potassium in M1. This rising triglyceride value would correspond to hypertriglyceridemia and would be a risk factor for predicting cardiovascular disease, according to [2, 12, 28]. This is because triglycerides are the main constituents of cell membranes and the increase in their concentration would probably be the result of apoptosis. Thus, M1 and M2 would obey this principle. As for the increase in LDLc in M1 and F2, it could favour the risk of coronary mortality because according to [24, 18, 28], its reduction would have the opposite effect. As for the transaminase elevation in F1, it could indicate hepatocellular damage or a disturbance of bile flow according to $[11,28]$. Elevated ionogram values $(\mathrm{Na}, \mathrm{Cl}$ and $\mathrm{K}$ ) in F1, and blood glucose levels in F1 and M2 would indicate heart disease and diabetes respectively according to $[30,28]$. In $\mathrm{M} 2$, the decrease in transaminases would reveal a vitamin B6 deficiency according to [5]. As for dyskalemia (potassium variation) in $\mathrm{M} 1$ and $\mathrm{M} 2$, it would be the basis of neuromuscular and cardiac signs according to [20]. The same author states that potassium plays a major role in the maintenance of the resting membrane potential. This observation was confirmed by [3] states that dyskalemia (hyperkalemia or hypokalemia) is life threatening. Thus, the various pathologies mentioned above would be linked to the action of venom on the vital organs of the various animals solicited, which would lead to their death.

\section{CONCLUSION}

This study, which aimed to understand the action of venom on the biochemical parameters of rabbits, revealed that:

- The venom of Naja nigricollis at a certain dose has a dose-dependent hemolysing power in vitro and in vivo;

- with a few exceptions, the biochemical parameters of males are generally higher than those of females;

- the venom of Naja nigricollis causes renal failure and cardiovascular disease in some animals, promotes a risk of coronary mortality and diabetes in others, causes neuromuscular and cardiac signs due to dyskalemia in others, and finally a hepatocellular damage or disruption of bile flow, a heart problem and vitamin B6 deficiency in one type of animal;

- The venom of Naja nigricollis is fatal.

\section{REFERENCES}

1. Abenga JN and Anosa VO. Serum total proteins and creatinine levels in experimental Gambian trypanosomosis of vervet monkeys. African Journal of Biotechnology. 2005; 4: 187-190.

2. Al-Shinnawy M. Vitamin $\mathrm{C}$ as ameliorative agent against thiodicarb toxicated male albino rats (Rattus norvegicus). Egyptian Academic Journal of Biological Science. 2008; 1(2):177-187.
3. Anonymous. Chapter 3-Item 265: Potassium balance anomalies. 2018; 43-60.

Available from http://cuen.fr/manuel/IMG/pdf/03nephrologie_8e-edition_chap3.pdf

4. Brown GV, Warrell DA. Venomous bites and stings in the tropical world. The Medical Journal of Australia. 1993; 159:773-779.

5. Carip C. Physiopathology: Physiopathological bases of dietetics. In Chapter 4: Hepatobiliary pathology. $3^{\text {th }}$ Edition, Lavoisier TEC \& DOC, Paris, France. 2014; 71-87.

6. Chippaux JP. Snake venoms and poisonings. RID Editions Research Institute for Development, Didactic Collection, Paris, France. 2002; 293.

7. Chippaux JP. The snakes of West and Central Africa. Tropical Fauna and Flora Collection, 2006; 35:11-329.

8. Chippaux JP. Estimate of the burden of snakebites in sub-Saharan Africa: A meta analytic approach. Toxicon. 2011; 57(4):586-599.

9. Chippaux JP, Goyffon M. Epidemiology of envenimations in the world. In G. Mion, M. Goyffon. Serious envenimations.. Paris : Arnette. 2000; 1-7.

10. Coulibaly FA, Coulibaly A, N'guessan JD, Kouamé KG, Djaman AJ, Guédé-Guina F. Study of biochemical serum parameters: the case of rabbits (Neozelandais-cunistar) from Côte d'Ivoire. Science \& Nature. 2007; 4(1):37-43.

11. Diaby V. Biochemical, hematological and histological studies of cadmium sulfate in Wistar rats. Félix Houphouët-Boigny University, Abidjan, Côte d'ivoire. 2017; 130.

12. Djeffal A. Evaluation of the toxicity of a carbamate insecticide "methomyl" in Wistar rats: Oxidative stress and exploration of the protective effects of selenium and/or vitamin C supplementation. Badji Mokhtar-Annaba University, Algeria. 2014; 170.

13. Djerrou Z. Study of the pharmaco toxicological effects of medicinal plants from Algeria: Healing activity and safety of Pistacia lentiscus L. vegetable oil. Mentouri University of Constantine, Algeria. 2011; 131.

14. Dramé BSI. Snake bite poisoning accidents at the Gabriel Touré Hospital's Surgical Emergency Department. University of Mali. 2000; 72.

15. Fumba G. Anti-venomous medicinal plants from Burundi. The presses of the future, Arlon, Belgium. 1983; 136.

16. Grema M and Koné PP. Effects of the venom of a snake (Bitis arietans) and an antivenomous plant from the traditional African pharmacopoeia (Annona senegalensis) at the sciatic nerve junction of the gastrocnemius muscle of a toad (Buffo regularis). CAMES Review - Series A. 2003; 02:79-85.

17. Hamza L. Biological and biochemical characterization of the hemorrhagic and myonecrotic activities of the venom of Vipera 
lebetina. University of Science and Technology Houari Boumediene, Algeria. 2001; 127.

18. Heuillet M. Development of reference methods for biomarkers of lipid balance: application to quality control in clinical biology. University of Bourgogne, Paris, France. 2013; 199.

19. Hilali M., Abdel-Gawad A, Nassar A, AbdelWahab A. Hematological and biochemical changes in water buffalo calves (Bubalus bubalis) infected with Trypanosoma evansi. Veterinary Parasitology. 2006; 139:237-243.

20. Ichai C. Dyskalemia. 2012; 20. Available from https://sofia.medicalistes.fr/spip/IMG/pdf/Les_dys kaliemies.pdf

21. Kassogué A. Renal complications of snake bite poisoning at SUC HGT from January to December 2004. University of Bamako, Mali. 2006; 86.

22. Larréché S. Viperidated infections in the Republic of Djibouti from October 1994 to May 2006: Retrospective study in the intensive care unit of the medical-surgical group Bouffard. University of Paris Val-de-Marne, France. 2007; 155.

23. Larréché S, Mion G, Clapson P, Debien B, Wybrecht D, Goyffon M. Neurotoxins from snake venom. French Annals of Anesthesia and Reanimation. 2008; 27 (4): 310-316.

24. Lewington S, Whitlock G, Clarke R, Sherliker P, Emberson J, Halsey J, Qizilbash N, Peto R, Collins R. Blood cholesterol and vascular mortality by age, sex, and blood pressure: a meta- analysis of individual data from 61 prospective studies with 55,000 vascular deaths. Lancet. 2007; 370:1829-1839.

25. Mion G, Olive F. Envenimation by the viperides (in Africa). Reanimation in Tropical Medicine, Paris, France. 1998; 349-365.

26. Mion G, Larréché S. Cobraic syndrome. Tropical Medicine. 2008; 68: 348-358.

27. Nelson BK.Snake envenomation Incidence. Clinical presentation and mangement. Medical Toxicology adverse drug experience. 1989; 4:1731.

28. Obou Constantin Okou, Djako Sosthène Thierry Akré, Gomé Michel Bleu, Assandé Francis Ehounou, Alain Dit Philippe Bidié. Study of the variation of some biochemical parameters in Rattus norgevicus. Asian Journal Research in Biochemistry. 2020; 7(4):21-34.

29. Pollet L, Ponchel C, Carpentier JP. Cobraic Envenimation. In G. Mion , M. Goyffon. Serious envenimations. Paris: Arnette. 2000; 53-64.

30. Siby S. Study of the variation of biochemical and hematological parameters in the district of Bamako. University of Bamako, Mali. 2008; 77.

31. Zabré ZM. Determination of the usual biochemical parameters in small ruminants in Burkina-Faso and their variations in subjects naturally infected by trypanosomosis. Cheikh Anta Diop University, Dakar, Senegal, 2013; 71. 